\title{
Literature Survey of previous research work in Models and Methodologies in Project Management
}

\author{
Ravinder Singh \\ AVP, JP Morgan Chase \& Co \\ Research Scholar, \\ Department of Informatics, \\ King's College, London, UK
}

\author{
Dr. Kevin Lano \\ Reader \\ Department of Informatics, \\ King's College, London, UK
}

\begin{abstract}
This paper provides a survey of the existing literature and research carried out in the area of project management using different models, methodologies, and frameworks. Project Management (PM) broadly means programme management, portfolio management, practice management, project management office, etc. A project management system has a set of processes, procedures, framework, methods, tools, methodologies, techniques, resources, etc. which are used to manage the full life cycle of projects. This also means to create risk, quality, performance, and other management plans to monitor and manage the projects efficiently and effectively.
\end{abstract}

Keywords-Programme/ Program Management, Project Management, Maturity Models, Onshore-offshore Management, Leadership and Management, Global Distributed Projects

\section{INTRODUCTION}

Projects are considered at all levels of organisation which may involve one or many business units and they can involve one or 100s of persons. The duration of projects can vary from a few weeks to many years. Projects can be simple to highly complex projects, which may be implemented at one location or multiple locations across multiple countries.

There are two main PM standards i.e. Project Management Body of Knowledge (PMBOK) by PMI, USA and PRINCE-2 by APMG, UK.

Considering the PMBOK and PRINCE-2 standard as the base, models may be defined for the process and knowledge management areas of PM. The benefits of having models includes support for defining tools for project management, deliverables and documentation, and to improve consistency between different areas and processes of PMBOK. It may be able to benefit other projects as the tools, documents and deliverables can be reused. The use of modelling will also bring consistency and reliability in the management of various projects. This will make project monitoring and controlling easier during the execution and whole life cycle of the project. The final advantage will come in the form of delivering good quality projects on time, budget and scope with improved quality. This will lead to overall customer satisfaction as risk and issues have been managed efficiently and effectively.

According to an independent study, undertaken and conducted by Loudhouse Research, on behalf of CA in 2007 on the "The changing face of project management" studying the Project panorama in UK corporates and observing the project failure as well as excellence. Study redefines the failure, emphasising the strategic value the projects deliver rather than exclusively on delivery within budget and time.

- $26 \%$ of surveyed companies are spending more than half of IT budget on IT projects

- Average company is managing 29 projects at once and 1 in 10 companies is managing more than 100 projects at a time

- More than half of IT Directors (52\%) think projects are more complex than 5 years ago, fuelled by increased demand from business $(62 \%)$ and a more pressurised regulatory environment $(55 \%)$

- For 59\%, less than half of initiatives are strategic.

- $53 \%$ projects are based on business processes improvement,

- $36 \%$ on growing revenues

- $32 \%$ on bringing new products/ services

Survey also covered various issues in managing projects effectively. Some of these are as follows:

- Typical budget over-runs 30\%; 1 in 6 projects going more than $50 \%$ over budget; 10 out of 29 projects on the go at one time will come in over budget

- Inaccurate scoping and forecasting is blamed for budget over-runs in half of cases (50\%). With scope creep responsible in 4 out of 10 cases.

- Only a 3rd (35\%) of businesses check that initiatives are aligned with business objectives with only 1 in 8 companies basing this decision on real time, accurate information.

- $74 \%$ struggle to access critical skills

- $39 \%$ of IT Directors don't have complete visibility over all IT initiatives in progress

- $42 \%$ of IT directors know within a day if an initiative is off-course

Therefore a standard methodology is required to deliver the projects efficiently and effectively within time and budget. 
There are two main standards for project management i.e. Project Management Body of Knowledge (PMBOK) by PMI, USA and PRINCE-2 by APMG, UK. PMBOK is more dominant standard as this is used in more than $75 \%$ of the projects around the world.

Software/ IT projects use various methodologies such as SSADM, RUP, Spiral Model, Scrum, Extreme Programming, etc. and management methodologies such as PMBOK, PRINCE2.

According to Project Management Body of Knowledge (PMBOK) [1], a project is a temporary endeavour undertaken to create a unique product, service or result. According to PMBOK project management is realised through the combination and practice of five project management processes: Initiating, Planning, Executing, Monitoring and Controlling, and Closing. PMBOK divides project management into ten knowledge areas of Integration, Scope, Time, Cost, Quality, Human Resource, Communication, Risk, Procurement, and Stakeholder Management. Project management is the effective use of processes, procedures, tools, techniques along with knowledge, and skills to meet project objectives. Project managers have to manage the traditional Triple constraints - "Scope, Time, and Cost", which have been enhanced in recent time with three more constraints called "Quality, Risk and Customer Satisfaction".

PRINCE2 [2] describes a project as "A management environment that is created for the purpose of delivering one or more business products according to specified business needs". The PRINCE2 process model comprises of eight distinctive management processes namely Starting up a Project (SU), Directing a Project (DP), Initiating A Project (IP), Planning (PL), Managing Stage Boundaries (SB),
Controlling a Stage (CS), Managing Product Delivery (MP), Closing a Project (CP) which covers the full life cycle of a project. PRINCE2 is a de facto standard used extensively in UK government.

A key standard amongst maturity models for Portfolio, Programme, and Project Management is P3M3 [3]. This offers a framework for organizations with which they can assess their current performance and develop/ implement improvement plans with measurable outcomes based on industry best practice

\section{PROJect Management Body OF KNOWLEDGE (PMBOK)}

PMI (USA) developed a Project Management Body of Knowledge (PMBOK) [1], which can be described as collection of project management knowledge. Similar to other professions like engineering, medicine, accounting etc., this body of knowledge rests with professionals in the project management field who uses this knowledge and also propose advancements in it. PMBOK provides good practices, knowledge, tools, skills, and techniques for better, efficient and effective project management. It does not mean that all the things described can be applied to all projects, but has to be modelled and tailored depending on the various constraints of the project like size, budget, time, location etc. PMBOK also describes the common terminology and language for project documentation, reports, writing etc. This makes it easier for all to understand and work on the project by reducing the communication gap.

According to PMBOK [1], differences among project, program and portfolio management is as follows in Table 1.1:

Table 1-1. Comparative Overview of Project, Program, and Portfolio Management

\begin{tabular}{|c|c|c|c|}
\hline & PROJEGTS & PROGRAMS & PORTFOLIOS \\
\hline Scope & $\begin{array}{l}\text { Projects have defined } \\
\text { objectives. Scope is progres- } \\
\text { sively elaborated throughout } \\
\text { the project life cycle. }\end{array}$ & $\begin{array}{l}\text { Programs have a larger scope } \\
\text { and provide more significant } \\
\text { benefits. }\end{array}$ & $\begin{array}{l}\text { Portfolios have a business } \\
\text { scope that changes with the } \\
\text { strategic goals of the organiza- } \\
\text { tion. }\end{array}$ \\
\hline Change & $\begin{array}{l}\text { Project managers expect } \\
\text { change and implement } \\
\text { processes to keep change } \\
\text { managed and controlled. }\end{array}$ & $\begin{array}{l}\text { The program manager must } \\
\text { expect change from both inside } \\
\text { and outside the program and be } \\
\text { prepared to manage it. }\end{array}$ & $\begin{array}{l}\text { Portfolio managers continually } \\
\text { monitor changes in the broad } \\
\text { environment. }\end{array}$ \\
\hline Planning & $\begin{array}{l}\text { Project managers progressively } \\
\text { elaborate high-level information } \\
\text { into detailed plans throughout } \\
\text { the project life cycle. }\end{array}$ & $\begin{array}{l}\text { Program managers develop the } \\
\text { overall program plan and create } \\
\text { high-level plans to guide } \\
\text { detailed planning at the } \\
\text { component level. }\end{array}$ & $\begin{array}{l}\text { Portfolio managers create and } \\
\text { maintain necessary processes } \\
\text { and communication relative to } \\
\text { the aggregate portfolio. }\end{array}$ \\
\hline Management & $\begin{array}{l}\text { Project managers manage the } \\
\text { project team to meet the } \\
\text { project objectives. }\end{array}$ & $\begin{array}{l}\text { Program managers manage the } \\
\text { program staff and the project } \\
\text { managers; they provide vision } \\
\text { and overall leadership. }\end{array}$ & $\begin{array}{l}\text { Portfolio managers may } \\
\text { manage or coordinate portfolio } \\
\text { management staff. }\end{array}$ \\
\hline Success & $\begin{array}{l}\text { Success is measured by } \\
\text { product and project quality, } \\
\text { timeliness, budget compliance, } \\
\text { and degree of customer } \\
\text { satisfaction. }\end{array}$ & $\begin{array}{l}\text { Success is measured by the } \\
\text { degree to which the program } \\
\text { satisfies the needs and benefits } \\
\text { for which it was undertaken. }\end{array}$ & $\begin{array}{l}\text { Success is measured in terms } \\
\text { of aggregate performance of } \\
\text { portfolio components. }\end{array}$ \\
\hline Monitoring & $\begin{array}{l}\text { Project managers monitor and } \\
\text { control the work of producing } \\
\text { the products, services or results } \\
\text { that the project was undertaken } \\
\text { to produce. }\end{array}$ & $\begin{array}{l}\text { Program managers monitor the } \\
\text { progress of program compo- } \\
\text { nents to ensure the overall } \\
\text { goals, schedules, budget, and } \\
\text { benefits of the program will be } \\
\text { met. }\end{array}$ & $\begin{array}{l}\text { Portfolio managers monitor } \\
\text { aggregate performance and } \\
\text { value indicators. }\end{array}$ \\
\hline
\end{tabular}


PMBOK [1] defines a project as follows:

$\checkmark$ A temporary endeavour to create a unique product, service or a result.

$\checkmark \quad$ Creates a unique product, service or result.

$\checkmark$ Is progressively elaborated $\quad-$ distinguishing characteristics of each unique project will be progressively detailed as the project is better understood.

\section{According to PMBOK [1]:}

- Temporary means that every project has a definite beginning and a definite end. Projects are not on-going efforts.

- Unique Product means a product or an artifact that is produced, is quantifiable, and can be either an end item in itself or component item.

- A capability to perform a service, such as business functions supporting production or distribution.

- A result such as outcomes or documents e.g. research project.

Progressive Elaboration is a characteristic of projects that accompanies the concepts of temporary and unique. This means developing in steps and continuing by increments. Progressive elaboration is not scope creep.

Management by objectives (MBO) has three steps:

$\checkmark \quad$ Establish unambiguous and realistic objectives.

$\checkmark$ Periodically evaluate if objectives are being met.

$\checkmark$ Implement corrective action.

Project managers have to manage the traditional triple constraints of Cost, Time, and Scope. The new demands in the project management emphasises three more constraints of Quality, Risk, and Customer Satisfaction which the project manager should manage. Prioritisation of the constraints may be managed by the management directly or indirectly.

The stakeholder in the project is someone whose interests and whose influence may be positively or negatively impacted by the projected. Negative stakeholders are often overlooked by the project team at the risk of failing to bring their project to successful end. The key stakeholders in the project are project manager, customer, performing organisation, users, project team, sponsor, and project management office (PMO). All of the stakeholders must be identified, documenting their requirements, communicating and managing their expectations and influences on the project. Project management team has professional responsibility towards all of its stakeholders and public in general. PMI members must adhere to the "Code of Ethics" and Project Management Professionals (PMP)" certification should adhere to a "Code of Professional Conduct".

Projects are approved depending on the strategic objectives of the organisation such as Market demand, organisational need, customer request, technology advance, legal requirement, etc.
Project management system is described as a set of tools, techniques, methodologies, resources and procedures. PMI divides project management into professional and social responsibility knowledge areas and process groups. The PMBOK describes the integration among project management processes, the relations among them and function they serve.

PMBOK combines these processes into five process groups which are defined as Project Management Process Groups which are Initiating Process Group, Planning Process Group, Executing Process Group, Monitoring and Controlling Process Group, and Closing Process Group.

Even though the project management processes are presented as discrete elements, but they overlap and project management professionals can me manage the project in different ways. The objectives of the projects can be defined based on the complexity, risk, size, time, resources, documents, deliverables, application area, geographic spread, experience, and maturity of team and organisation. The concept of interaction and overlapping of PM processes can be traced to Plan-Do-Check-Act (PDCA) cycle.

The Planning Process Group corresponds to "Plan" component of PDCA, the Executing Process Group corresponds to "Do" component of PDCA, the Monitoring and Controlling Process Group corresponds to "Check and Act" component of PDCA as shown in the Figure 1 below:

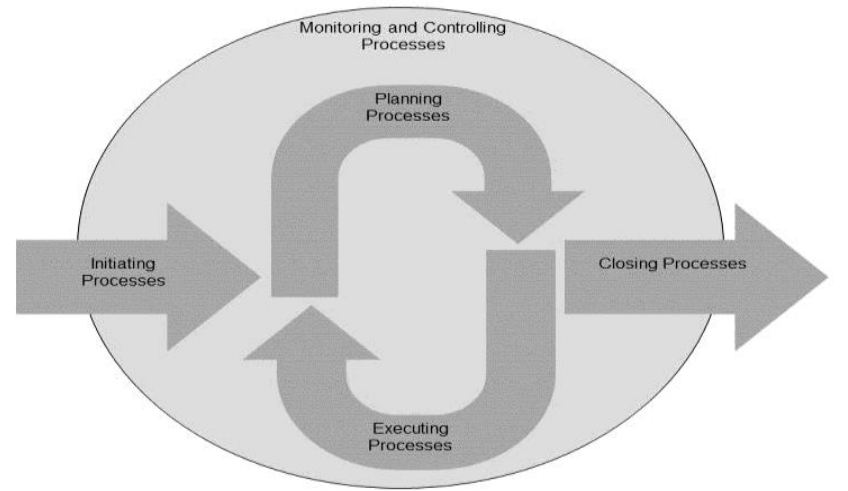

Project Management Process Groups mapped to the PDCA Cycle (Plan-Do-Check-Act

Fig.1. Project Management Processes as PDCA cycle

PMI further divides the project management into ten Knowledge Areas which are Project Integration Management, Project Scope Management, Project Time Management, Project Cost Management, Project Quality Management, Project Human Resources Management, Project Communications Management, Project Risk Management, Project Procurement Management, and Project Stakeholder Management.

Project Integration Management: it describes the processes and activities which integrate various components of the project.

Project Scope Management: This describes the processes which are used to calculate the scope, and only the work required, for successful completion of the project. 
Project Time Management: defines the processes for completing the project on time.

Project Cost Management: describes process for estimating, planning, budgeting and controlling the cost of the project.

Project Quality Management: defines the processes for assuring that the project is delivered as per the required standard and objectives.

Project Human Resource Management: defines the processes for managing the human resources for the project.

Project Communication Management: describes the collecting, processes for processing, sending and receiving the information to the appropriate channels.

Project Risk Management: describes the processes for managing, prioritising, and mitigating risk for the project.

Project Procurement Management: describes the processes for contract management for purchasing any services, results or products.

Project Stakeholder Management: discusses the processes for managing stakeholders and understanding their expectations and managing them effectively.

\section{PRINCE-2}

PRINCE (PRojects IN Controlled Environments) [2] is a structured method for effective project management. The method was developed first in 1989 by CCTA (The Central Computer and Telecommunication Agency). The method was adopted from PROMPTII, a project management method developed by Simpact Systems Ltd in 1975. Office of Government (earlier CCTA) further enhanced the method continuously and PRINCE-2 was launched in 1996. PRINCE2 is based on the information and experiences shared by various experts, professionals in project management field.

PRINCE-2 is a de-facto standard used extensively by UK government. This is also used widely in private sector, but more in UK than internationally.

PRINCE-2 defines a project as, "A management environment that is created for the purpose of delivering one or more business products according to a specified business case". Another definition of project according to PRINCE-2 is, "A temporary organisation that is needed to produce a unique and predefined outcome or result at a pre-specified time using predetermined resources".

According to Prince-2, project has the following characteristics:

- A finite and defined life cycle.

- Defined and measurable business products.

- A corresponding set of activities to achieve the business products.
- A defined amount of resources.

- An organisation structure, with defined responsibilities, to manage the project.

The PRINCE-2 process model is shown in the Figure 2 This model consists of eight distinctive management processes for the full life cycle of the project. The Planning process is used by four of the other processes.

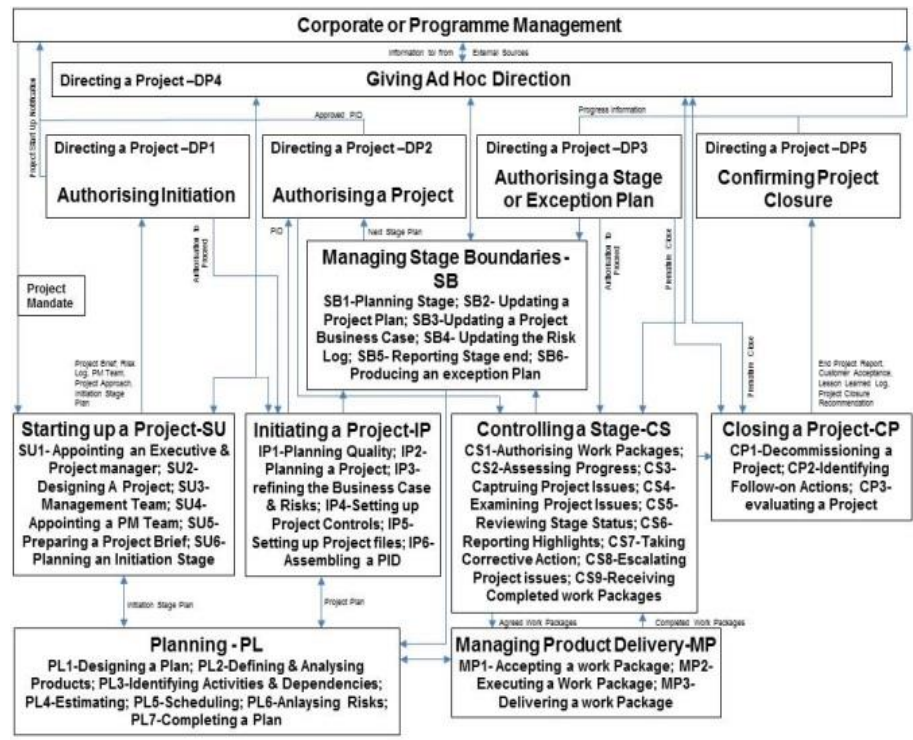

Fig.2. PRINCE-2 Process Flow

A project must be able to make use of each of these processes in some form, and this may require tailoring of the processes for the needs of the individual project. Each process should be followed by asking a question about the relevance of the process for the particular project.

\section{PRINCE-2 STRENGTHS}

- Organization (Project Boards; defined roles and responsibilities; ownership \& accountability)

- Business case-based; on-going assessment of project viability by project owners (Board)

- Product-Based Planning (strictly deliverable oriented); Product Flow; Product Descriptions

- Integrated process structure: clear statement of how to manage the project ("How do I get started? What do I do first?")

- Clear quality management points (esp. Quality Control), and Quality Assurance roles and responsibilities

- Defined and orderly handling of Work Packages (Managing Product Delivery)

\section{PMBOK AND PRINCE-2 COMPARISON}

Basic contrast between PMBOK and PRINCE-2 is as follows in Table-2: 
TABLE.II. PMBOK VS PRINCE-2

\begin{tabular}{|l|l|}
\hline PMBOK & PRINCE-2 \\
\hline Comprehensive & $\begin{array}{l}\text { Focusses on key risk areas only; } \\
\text { does not claim to be complete }\end{array}$ \\
\hline $\begin{array}{l}\text { Largely descriptive, prescriptive on a } \\
\text { high level }\end{array}$ & $\begin{array}{l}\text { Highly prescriptive, especially on } \\
\text { Process Structure, but adaptable to } \\
\text { any size project }\end{array}$ \\
\hline $\begin{array}{l}\text { Core and facilitating processes; need } \\
\text { to be scaled to the needs of the } \\
\text { project }\end{array}$ & $\begin{array}{l}\text { All processes should be considered; } \\
\text { also need to be scaled }\end{array}$ \\
\hline Customer requirements driven & Business case driven \\
\hline Sponsor and stakeholders & $\begin{array}{l}\text { Clear project ownership and } \\
\text { direction by senior management }\end{array}$ \\
\hline International/ UK standard & UK standard \\
\hline
\end{tabular}

PRINCE2 is built on seven elements, or Themes: Business Case, Organization, Plans, Progress, Risk, Quality, and Change (comprising configuration management and change control). They roughly map against the nine PMBOK Knowledge areas as follows in Table-3:

TABLE.III. KNOWLEDGE AREAS PMBOK Vs PRINCE-2

\begin{tabular}{|l|l|}
\hline PMBOK Knowledge areas & PRINCE-2 components/ Themes \\
\hline Integration & $\begin{array}{l}\text { Combined Processes and } \\
\text { Components/ Themes, Change } \\
\text { Control }\end{array}$ \\
\hline Scope, Time Cost & Plans, Business Case \\
\hline Quality & $\begin{array}{l}\text { Quality, Configuration } \\
\text { Management (Change) }\end{array}$ \\
\hline Risk & Risk \\
\hline Communications & Controls \\
\hline HR & Organisation (limited) \\
\hline
\end{tabular}

\begin{tabular}{|l|l|}
\hline Procurement & Not Covered \\
\hline Stakeholder & Not Covered \\
\hline
\end{tabular}

Five processes groups of PMBOK map against the PRINCE-2 processes as follows in Table-4:

TABLE.IV. PROCESS AREAS PMBOK VS PRINCE-2

\begin{tabular}{|l|l|l|}
\hline PMBOK & $\begin{array}{l}\text { PRINCE-2 } \\
\text { (Project Level) }\end{array}$ & $\begin{array}{l}\text { PRINCE-2 (Stage } \\
\text { Level) }\end{array}$ \\
\hline Initiating & $\begin{array}{l}\text { Starting Up; } \\
\text { Directing }\end{array}$ & $\begin{array}{l}\text { Managing Stage } \\
\text { Boundaries; } \\
\text { Directing }\end{array}$ \\
\hline Elanning & $\begin{array}{l}\text { Initiating, } \\
\text { Planning }\end{array}$ & $\begin{array}{l}\text { Managing Stage } \\
\text { Boundaries; } \\
\text { Planning }\end{array}$ \\
\hline Executing/ Controlling & $\begin{array}{l}\text { Managed on a } \\
\text { stage-by-stage } \\
\text { basis }\end{array}$ & $\begin{array}{l}\text { Controlling a } \\
\text { Stage; Managing } \\
\text { Product Delivery; } \\
\text { Directing }\end{array}$ \\
\hline Closing & Closing a Project & $\begin{array}{l}\text { Managing Stage } \\
\text { Boundaries }\end{array}$ \\
\hline
\end{tabular}

\section{LITERATURE SURVEY}

Previous research had been focusing on different aspects of the program and project management such as study of models and framework, empirical, and statistical studies. The studies had been conducted in different industry sectors but most of the research has been in the software and IT industry as given below in Table-5.

TABLE.V. LITERATURE SURVEY

\begin{tabular}{|c|c|c|c|}
\hline $\begin{array}{l}\text { Ref. } \\
\text { No. }\end{array}$ & $\begin{array}{l}\text { Category/ } \\
\text { Topic }\end{array}$ & $\begin{array}{l}\text { Study Description/ Method/ Argument/ Theoretical } \\
\text { Approach }\end{array}$ & Results, gaps, and Conclusions \\
\hline & \multirow{4}{*}{$\begin{array}{l}\text { Project } \\
\text { Management } \\
\text { Models/ } \\
\text { frameworks }\end{array}$} & \multicolumn{2}{|c|}{$\begin{array}{l}\text { The following papers [4-8] have used existing project management models and/ or framework for the studies and proposed a few } \\
\text { modifications and amendments to make it more effective and efficient. }\end{array}$} \\
\hline 4. & & $\begin{array}{l}\text { This paper discussed and compared project management / } \\
\text { frameworks for managing software projects. } \\
\text { Authors compared five different methodologies with } \\
\text { PMBOK. } \\
\text { This research can be of useful help for projects managers to } \\
\text { decide on particular methodology for different projects. }\end{array}$ & $\begin{array}{l}\text { This research suggests that project manager must have skills and } \\
\text { knowledge of various methodologies used for successful completion of } \\
\text { projects. } \\
\text { The research highlighted that organisation adhere to one methodology due } \\
\text { to cost involved, risks associated with other, and training required for its } \\
\text { staff. The paper proposed a generic approach to project management. }\end{array}$ \\
\hline 5. & & $\begin{array}{l}\text { This research paper discussed three concepts for project } \\
\text { approach. } \\
\text { The first step is to develop global project framework for } \\
\text { defining objectives, project life cycle and possible steps for } \\
\text { projects repeatability. } \\
\text { The } 2^{\text {nd }} \text { step is to analyse and build project specifications, } \\
\text { plans using transition graphs, and performance measurement } \\
\text { baselines. } \\
\text { Final step is to describe organisation design, roles, job } \\
\text { specifications, deliverables and timelines, etc. for project } \\
\text { manager and teams. }\end{array}$ & $\begin{array}{l}\text { The paper proposed to follow one specific model but at the same time } \\
\text { suggests changing the model dynamically with the project needs using } \\
\text { modular and flexible approach. } \\
\text { The results showed that projects can be managed in a better manner with } \\
\text { clear deliverables and milestones using three step approach. } \\
\text { The dynamic change in the deliverables/ milestones helps to manage risks } \\
\text { and issues. }\end{array}$ \\
\hline 6. & & $\begin{array}{l}\text { The research decomposed the Industrial System development } \\
\text { into number of phases. } \\
\text { Defined the organisation process with results and deliverables } \\
\text { i.e. documents or system components which are to be }\end{array}$ & $\begin{array}{l}\text { The research proposed that a bigger system can be managed effectively } \\
\text { and efficiently by converting it into smaller phases of planning, analysis, } \\
\text { functional and technical design, build, test (unit, assembly, UAT, } \\
\text { performance etc.), implementation and maintenance. } \\
\text { Furthermore each phase can have transitions to effectively move from one }\end{array}$ \\
\hline
\end{tabular}




\begin{tabular}{|c|c|c|c|}
\hline & & $\begin{array}{l}\text { transitioned from one phase to another. } \\
\text { Studied different systems and proposed a new mode which } \\
\text { was evaluated on another system showing better results. }\end{array}$ & $\begin{array}{l}\text { phase to next. The transitions can be managed effectively with some } \\
\text { people moving from one phase to next phase so that knowledge can be } \\
\text { transferred fully. }\end{array}$ \\
\hline 7. & & $\begin{array}{l}\text { This research used object based models for better co- } \\
\text { ordination of complex projects. } \\
\text { Models used on chip design, identifying problems/ issues with } \\
\text { PM tools. } \\
\text { Object based models were created to overcome the above } \\
\text { issues and summarise the stages/ phases of the project in } \\
\text { better way for the project manager. }\end{array}$ & $\begin{array}{l}\text { The object based model provided value addition by increasing the stability } \\
\text { of the projects, co-ordination between PM tools and structure approach, } \\
\text { and hence reducing uncertainty. } \\
\text { Model used properties of inheritance from one phase to next, modularity to } \\
\text { break project into small pieces of work, using relation to define } \\
\text { interactivity. Data hiding is used to provide information/ access to the } \\
\text { authorised people. }\end{array}$ \\
\hline \multirow[t]{2}{*}{8.} & & $\begin{array}{l}\text { This research highlighted that standard project management } \\
\text { methodologies should be used by project managers. } \\
\text { Project manager should create his/her own set of required } \\
\text { documents, deliverables, processes etc. for more efficient } \\
\text { approach and better synergy among various project activities } \\
\text { and resources. }\end{array}$ & $\begin{array}{l}\text { The paper proposed that project managers should tailor the standard } \\
\text { project management processes as per their requirements so as to enhance } \\
\text { the efficiency and synergy among project activities and resources. } \\
\text { The tailoring could be in terms of deliverables, documents, tools, methods, } \\
\text { etc. to be used depending upon the complexity of the project. }\end{array}$ \\
\hline & \multirow{12}{*}{$\begin{array}{l}\text { Use of } \\
\text { Modelling in } \\
\text { Project } \\
\text { Management }\end{array}$} & \multicolumn{2}{|c|}{$\begin{array}{l}\text { The following papers [9-12] have tried to implement the system modelling, estimation and object oriented concepts for better project } \\
\text { management. }\end{array}$} \\
\hline \multirow[t]{2}{*}{9.} & & $\begin{array}{l}\text { This research paper proposed a methodology to integrate the } \\
\text { use of system dynamics approach to manage risks within the } \\
\text { existing project management processes. }\end{array}$ & $\begin{array}{c}\text { Paper suggested the use of System dynamic modelling and framework } \\
\text { within PMBOK processes for better management and control of risks in } \\
\text { projects. }\end{array}$ \\
\hline & & $\begin{array}{l}\text { Project risks change dynamically as the projects are being run } \\
\text { and are difficult to predict and manage, this paper suggested } \\
\text { the use of system dynamic modelling and framework for } \\
\text { better monitoring and control within the PMBOK risk } \\
\text { management processes. }\end{array}$ & $\begin{array}{l}\text { Dynamic modelling provides better control of risks and project managers } \\
\text { will be able to forecast and manage project milestones more effectively. }\end{array}$ \\
\hline \multirow[t]{4}{*}{10.} & & $\begin{array}{l}\text { This research suggested the use of system modelling as } \\
\text { communication tool for evaluating and gathering stakeholder }\end{array}$ & $\begin{array}{l}\text { The research showed that System modelling could bridge the } \\
\text { communication gap between clients and project managers. }\end{array}$ \\
\hline & & $\begin{array}{l}\text { Since communication levels and skills are different for project } \\
\text { managers and business stakeholders, and hence there is a gap }\end{array}$ & $\begin{array}{l}\text { PMs would be able to define models to define communications channels, } \\
\text { means, processes, and manage the objectives, requirements, and } \\
\text { expectations effectively and efficiently. }\end{array}$ \\
\hline & & $\begin{array}{l}\text { among customer expectations. This results in scope changes, } \\
\text { time and budget changes, and quality. }\end{array}$ & $\begin{array}{l}\text { The research shows that model would be able to provide framework to } \\
\text { reduce communication gap and understand stakeholder expectation, which }\end{array}$ \\
\hline & & $\begin{array}{l}\text { System modelling was used at MIT-Portugal Green Islands } \\
\text { project. The results show that the communication gap can be } \\
\text { bridged and stakeholders' expectations would be satisfied } \\
\text { more effectively. }\end{array}$ & resulted in better scope, time and budget control. \\
\hline \multirow[t]{3}{*}{11.} & & $\begin{array}{c}\text { This paper proposed the use of object oriented model for } \\
\text { project management. }\end{array}$ & \\
\hline & & $\begin{array}{l}\text { The hierarchical structure is used to represent the full } \\
\text { development life cycle of the software project and provide a } \\
\text { view of various parts to the project manager. }\end{array}$ & $\begin{array}{l}\text { Paper demonstrated the used of various object oriented properties like } \\
\text { inheritance, relations, modular, and data encapsulation for sharing } \\
\text { information through different phases of the life cycle of the project. }\end{array}$ \\
\hline & & $\begin{array}{l}\text { The interactivity among various components of the projects is } \\
\text { defined as relations among objects. }\end{array}$ & Various objects could be reused in different projects for better control. \\
\hline \multirow[t]{2}{*}{12.} & & $\begin{array}{l}\text { This paper proposed an estimation model for determining the } \\
\text { project effort based on use-case. Relationship between actual } \\
\text { and estimated data is developed to be used for better estimates } \\
\text { in future. }\end{array}$ & $\begin{array}{l}\text { The research suggested an estimation model based on actual and estimated } \\
\text { data to predict better results in future. } \\
\text { A mathematical model is created between actual and estimated data for } \\
\text { more accurate forecasting. }\end{array}$ \\
\hline & & $\begin{array}{l}\text { The model works better in iterative environments as it allows } \\
\text { comparing of successive developments. }\end{array}$ & This model is more suitable for iterative development environment. \\
\hline & \multirow{2}{*}{$\begin{array}{l}\text { Project } \\
\text { Management } \\
\text { in IT/ } \\
\text { Software } \\
\text { Projects }\end{array}$} & \multicolumn{2}{|c|}{$\begin{array}{l}\text { The research on software and IT projects had been discussed in the research papers [13-22]. Authors had explored not only the standard } \\
\text { project management methodologies like PMBOK, Prince2, RUP but also the new practices of Agile, JAD, RAD, extreme programming. } \\
\text { Researchers had also suggested adaptations of project management models for managing complex projects in the software and IT industry. }\end{array}$} \\
\hline 13. & & $\begin{array}{l}\text { This research paper discussed how the traditional process } \\
\text { models in software engineering are being modified/ replaced } \\
\text { with new web based models/ agile development due to more } \\
\text { dynamic nature of projects and fast changing requirements. }\end{array}$ & $\begin{array}{l}\text { The research paper discusses how the traditional processes have given way } \\
\text { to new web based, iterative, and incremental models which can cater to the } \\
\text { new demands and requirements in the fast and quick changing world. The } \\
\text { changes are expected in terms of look and feel, market demand, } \\
\text { technological advances, and providing more efficient services. }\end{array}$ \\
\hline
\end{tabular}




\begin{tabular}{|c|c|c|}
\hline & $\begin{array}{c}\text { The changes in the client expectations and requirements are } \\
\text { quick and frequent and hence requires new models which can } \\
\text { be iterative, incremental like Agile, JAD, RAD, Extreme } \\
\text { programming. }\end{array}$ & $\begin{array}{l}\text { It discusses various models like Agile, JAD, RAD, extreme programming } \\
\text { etc. These new models are capable of responding rapidly and meet } \\
\text { stakeholders' expectations. }\end{array}$ \\
\hline 14. & $\begin{array}{c}\text { This paper suggested that customisation and tailoring of } \\
\text { regular project management methodologies is required to } \\
\text { increase efficiency of processes in large scale complex } \\
\text { software projects. } \\
\text { The research provides guidelines and techniques for } \\
\text { developing generic models for process improvement. The } \\
\text { customised model would be more productive and having } \\
\text { better analysing capabilities as project manager would be able } \\
\text { to focus on the necessary requirements only. }\end{array}$ & $\begin{array}{l}\text { This research emphasised that regular project management methods/ } \\
\text { processes must be customised/ tailored in order to make it more efficient } \\
\text { and avoid unnecessary details. } \\
\text { The research found that customised models are better, more efficient and } \\
\text { effective due to better alignment with current scenarios and objectives. } \\
\text { This also provides project manager with better analytical skills to focus on } \\
\text { the necessary details. }\end{array}$ \\
\hline 15. & $\begin{array}{l}\text { This research suggested a simple and straightforward Project } \\
\text { Matrix model for technical project management of software } \\
\text { projects. } \\
\text { The model requires no special training or resources. }\end{array}$ & $\begin{array}{l}\text { The model is found to be efficient and highly effective in coordinating } \\
\text { resources monitoring and controlling software projects. } \\
\text { The paper demonstrated that model would be able to produce high quality } \\
\text { software projects with ease. }\end{array}$ \\
\hline 16. & $\begin{array}{l}\text { This paper proposed the integration of RUP and PMBOK for } \\
\text { managing technical software development process of product } \\
\text { lifecycle and management of project lifecycle respectively for } \\
\text { efficient and effective management of projects and delivering } \\
\text { high quality products. }\end{array}$ & $\begin{array}{l}\text { The paper suggested that organisation would be able to automate various } \\
\text { activities/ tasks in software development processes and project } \\
\text { management with the integration of RUP and PMBOK methodologies. } \\
\text { Using the capabilities of both RUP and PMBOK project manager would be } \\
\text { able to manage projects more efficiently. This would in turn lead to better } \\
\text { quality products. }\end{array}$ \\
\hline 17. & $\begin{array}{l}\text { This research paper proposed the integration of standard } \\
\text { software engineering practices with standard PM } \\
\text { methodologies and framework to create a new framework for } \\
\text { software development projects. }\end{array}$ & $\begin{array}{l}\text { The results showed that new integrated framework would help to develop } \\
\text { quality software project with better efficiency. } \\
\text { Paper used standard software engineering framework from Spiral model, } \\
\text { Waterfall model to create new framework integrated with PM } \\
\text { methodology. This provided better planning, monitor and control, and } \\
\text { execution of projects. }\end{array}$ \\
\hline 18. & $\begin{array}{l}\text { This research paper proposed to make optimum utilisation of } \\
\text { triple constraints of Time, Cost, and Scope as functions of } \\
\text { project's high-level requirements/ business objectives. The } \\
\text { new framework proposed extending the benefits of polarity } \\
\text { management to triple constraints of PMBOK. } \\
\text { Polarity management involves moving from focusing on one } \\
\text { pole as the problem and the other as the solution (either/or } \\
\text { thinking), to valuing both poles (both/and thinking). Good } \\
\text { polarity management gets the best of both poles while } \\
\text { avoiding the limits of either. }\end{array}$ & $\begin{array}{l}\text { This paper suggested that integration of new framework which uses triple } \\
\text { constraints as functions of business requirements/ objectives for optimum } \\
\text { utilisation. } \\
\text { It also suggested that polarity management could be used to manage the } \\
\text { triple constraints of PMBOK more effectively and efficiently, since these } \\
\text { constraints of time, cost, scope are opposite of each other. }\end{array}$ \\
\hline 19. & $\begin{array}{l}\text { Government IT projects were analysed critically by this } \\
\text { research. Authors tried to identify various challenges/ issues } \\
\text { faced by e-government projects. } \\
\text { The paper discussed the gaps in implementation of e- } \\
\text { government projects, their monitoring and control as well as } \\
\text { execution. }\end{array}$ & $\begin{array}{l}\text { This research studied e-government projects and challenges faced by these } \\
\text { projects. } \\
\text { The study proposed that appraisal should be more systematic and periodic } \\
\text { for successful completion. The appraisals have to be done in timely } \\
\text { manner, risks and issues highlighted and thus controlling the projects } \\
\text { efficiently. }\end{array}$ \\
\hline 20. & $\begin{array}{l}\text { This research suggested the use of T-cube and Metromap } \\
\text { visual tools for managing software development projects. } \\
\text { These techniques use graphical and metaphor presentations to } \\
\text { show various project management tasks. As the name suggests } \\
\text { these techniques use Rubik Cube and Metro map metaphors. }\end{array}$ & $\begin{array}{l}\text { The research proposed two techniques i.e. T-cube based on Rubik Cube } \\
\text { and Metromap and tested them on real project data and found that these } \\
\text { tools are effective and provide positive results for project management. } \\
\text { The method provides graphical presentation which is easy to view/ track/ } \\
\text { monitor the milestones and deliverables. This results in better project } \\
\text { management with improved visibility. }\end{array}$ \\
\hline 21. & $\begin{array}{l}\text { This paper suggested the application of software agent } \\
\text { framework to help in managing various processes of software } \\
\text { projects. } \\
\text { Two comprehensive frameworks were developed to assist all } \\
\text { the core and facilitating processes and functions of software } \\
\text { project management. }\end{array}$ & $\begin{array}{l}\text { The paper demonstrated that the use of software agent framework could } \\
\text { significantly help in meeting market expectations and deliver projects as } \\
\text { per the stakeholders' expectations adhering to schedule and budget. } \\
\text { The framework assigns each agent to manage a small and manageable } \\
\text { task, hence reducing complexity. The smaller tasks/ activities are easier to } \\
\text { manage and thus providing better monitoring and control of project. }\end{array}$ \\
\hline 22. & $\begin{array}{l}\text { This research discussed whether the existing project } \\
\text { management methodologies like PRINCE2 had been useful in } \\
\text { the management of software projects and information } \\
\text { systems. } \\
\text { Organisations have to develop full scale quality management }\end{array}$ & $\begin{array}{l}\text { The study suggested that the project managers may have to use some other } \\
\text { tools for effort and budget estimation like function point, empirical etc. } \\
\text { and performance measurement techniques along with standard project } \\
\text { management methodology. }\end{array}$ \\
\hline
\end{tabular}




\begin{tabular}{|c|c|c|c|}
\hline & & $\begin{array}{l}\text { plan to ensure delivering a good quality software product } \\
\text { efficiently and effectively. }\end{array}$ & $\begin{array}{l}\text { quality management plans to manage the projects in a better controlled } \\
\text { manner. }\end{array}$ \\
\hline & \multirow{3}{*}{$\begin{array}{l}\text { Managing } \\
\text { Projects in } \\
\text { R\&D } \\
\text { organisations }\end{array}$} & \multicolumn{2}{|c|}{$\begin{array}{l}\text { Differences between managing projects in R\&D organisations and other projects had been examined in papers [23-24]. Since R\&D projects } \\
\text { are knowledge intensive, hence gives rise to different set of requirements and expectations form stakeholders. }\end{array}$} \\
\hline 23. & & $\begin{array}{l}\text { This research discussed an approach that emphasises on } \\
\text { building relationship between project management and } \\
\text { engineering processes for better management and improved } \\
\text { performance of research projects and programmes. This had } \\
\text { been used at systems management office at NASA Langley } \\
\text { Research Centre. }\end{array}$ & $\begin{array}{l}\text { This approach suggested implementation of good project management } \\
\text { practices and processes with consultation of teams from the early stages } \\
\text { and improving them with tailor made training modules as and when } \\
\text { required using just-in-time approach. } \\
\text { This methodology also takes care of improvements in processes and } \\
\text { policies. The approach also emphasised on conducting reviews and } \\
\text { assessments independently for value addition. }\end{array}$ \\
\hline \multirow[t]{2}{*}{24.} & & $\begin{array}{l}\text { This research paper discussed and analysed the differences } \\
\text { among R\&D enterprises and other organisations. R\&D } \\
\text { enterprises being knowledge intensive, therefore more } \\
\text { emphasis has to be on knowledge management. Therefore a } \\
\text { culture of sharing knowledge by use of documentations, } \\
\text { templates, and shared information systems has to be created. }\end{array}$ & $\begin{array}{l}\text { This research confirmed that knowledge management system is needed to } \\
\text { strengthen the R\&D enterprise information system. } \\
\text { The sharing of knowledge through shared workspace, intranet sites, } \\
\text { documents, research papers, discussion and chat groups along with blogs } \\
\text { would provide easier sharing of information and knowledge in the } \\
\text { organisation. }\end{array}$ \\
\hline & \multirow{8}{*}{$\begin{array}{l}\text { Empirical } \\
\text { and } \\
\text { Statistical } \\
\text { Analysis }\end{array}$} & \multicolumn{2}{|c|}{$\begin{array}{l}\text { A number of empirical and statistical studies [25-33] had been conducted to investigate the success of various project management } \\
\text { methodologies and frameworks. Data has been collected and analysed using various techniques in order to understand the effectiveness of } \\
\text { diverse project management methodologies. }\end{array}$} \\
\hline 25. & & $\begin{array}{l}\text { This study conducted a survey to find the experiences of } \\
\text { people in project management. Survey finding were } \\
\text { highlighted in terms of various methods, tools, techniques } \\
\text { used and their effectiveness. Performance, project success } \\
\text { factors and common criteria for managing successful projects } \\
\text { were also studied. }\end{array}$ & $\begin{array}{l}\text { The survey found that people are using different tools and techniques for } \\
\text { similar kind of projects as per their skills, comfort level, and experience. } \\
\text { The tools are also sometimes prescribed by the organisation, limited by } \\
\text { legacy systems and availability. } \\
\text { Some PMs have also tailored the standard methodologies to suit their } \\
\text { needs. This provides them to model the system as per their needs and } \\
\text { requirements and hence reduce the cost. }\end{array}$ \\
\hline 26. & & $\begin{array}{l}\text { This research studied various factors that influence the } \\
\text { execution of project management and measure the } \\
\text { performance of project management methodologies. }\end{array}$ & $\begin{array}{c}\text { The study found that the } 6 \text { factors which have greater impact on execution } \\
\text { of project management are Management commitment, financial } \\
\text { constraints, organisational structure, reward system, education and training } \\
\text { of project teams. }\end{array}$ \\
\hline 27. & & $\begin{array}{l}\text { This research explained the importance of scope management } \\
\text { for successfully managing ICT projects. Standish group's } \\
\text { CHAOS report states that only } 1 / 3 \text { of ICT projects are } \\
\text { successful. Therefore project managers need to manage scope } \\
\text { and changes more efficiently and effectively. } \\
\text { This paper describes various approaches and techniques used } \\
\text { by the trained scope managers in USA, Europe and Australia } \\
\text { which have increased the success rate of the ICT project. }\end{array}$ & $\begin{array}{l}\text { This paper suggested that with proper scope management process in place } \\
\text { and with good training of PMs on scope and change management, ICT } \\
\text { projects can be completed more successfully. } \\
\text { Paper highlighted the use of standard methodologies like PMI, Prince-2, } \\
\text { and other PPM tools have helped the project managers to a great extent in } \\
\text { managing the scope and deliverables. It also showed that different } \\
\text { methodologies are popular in different countries. }\end{array}$ \\
\hline 28. & & $\begin{array}{l}\text { This research conducted an empirical study to identify the } \\
\text { important factors in the success of software process } \\
\text { management in software projects. The study was to find out } \\
\text { the importance and prioritisation of other factors like } \\
\text { baselining, user involvement, management commitment, } \\
\text { change management and documentation etc. for successful } \\
\text { completion of projects. }\end{array}$ & $\begin{array}{l}\text { Study found out that synchronisation/ synergy of activities/ tasks/ } \\
\text { processes is more important than other processes for the successful } \\
\text { management of software projects. } \\
\text { The study also found out that other factors for process management in } \\
\text { order of ranking were baselining, user involvement, management } \\
\text { commitment, change management, and documentation. }\end{array}$ \\
\hline 29. & & $\begin{array}{l}\text { This study tried to understand the effect of change on the } \\
\text { methods, practices, and performance of ICT projects. The } \\
\text { paper discussed the impact and challenges due to the dynamic } \\
\text { nature of work and environment in the current scenario. The } \\
\text { research focussed on finding the reasons for failure, and } \\
\text { reviewed the tools, techniques, practices, standards. The also } \\
\text { tried to analyse if these failure are due to changing, dynamic } \\
\text { or unstable nature of ICT projects and environment. }\end{array}$ & $\begin{array}{l}\text { The results showed that complexity of the projects had increased due to the } \\
\text { dynamic nature of projects and quick and fast changing market demand } \\
\text { and requirements. } \\
\text { The research highlighted the use of new tools, methods, frameworks, and } \\
\text { methodologies like Agile, RAD and software as a service, helps to deliver } \\
\text { quicker solutions at less cost. }\end{array}$ \\
\hline 30. & & $\begin{array}{l}\text { This paper discussed comparison had been done between } \\
\text { modern and traditional project management. Author also } \\
\text { discussed the key issues in the modern project management } \\
\text { and challenges faced in current environment. It also explored } \\
\text { the use or preference of one or other project management } \\
\text { methodology by the project manager due to which there will } \\
\text { be difficulty in managing projects which use different } \\
\text { methodology or framework. }\end{array}$ & $\begin{array}{l}\text { The paper suggested that in modern environment of ever changing } \\
\text { requirements, new methods, tools and techniques are required to face the } \\
\text { challenges and manage the projects effectively and efficiently. } \\
\text { Study highlighted that client methodology could be different to the service } \\
\text { provider and hence would create new challenges for project managers. }\end{array}$ \\
\hline 31. & & $\begin{array}{l}\text { This study explored the relation between project management } \\
\text { assets and performance by considering project management } \\
\text { assets as independent variables and project management } \\
\text { performance as dependent variables. To analyse the }\end{array}$ & $\begin{array}{l}\text { Seven factors were characterised for project management assets, three } \\
\text { factors for organisational support and two factors for project management } \\
\text { performance. The findings of the survey showed that project management } \\
\text { assets give a competitive advantage to the organisations. }\end{array}$ \\
\hline
\end{tabular}




\begin{tabular}{|c|c|c|c|}
\hline & & $\begin{array}{l}\text { advantage offered by project management assets, analysis of } \\
\text { online survey by } 198 \text { PMI members was done. }\end{array}$ & \\
\hline \multirow[t]{2}{*}{32.} & & $\begin{array}{l}\text { This research studied the application of PMBOK } 2008 \\
\text { standard processes to manage Enterprise Project Management } \\
\text { (EPM) system in one of the organisations. The authors } \\
\text { reviewed how the EPM project was implemented and its } \\
\text { status based on the data collected by them. They proposed } \\
\text { number of concepts to reduce the time and budget and } \\
\text { enhance the system for better efficiency. }\end{array}$ & $\begin{array}{l}\text { The study proposed that critical path management and PERT techniques } \\
\text { could be used along with customisation of processes for the needs of the } \\
\text { organisation. These methods help to track, monitor and control the } \\
\text { projects in a better manner with increased visibility of the critical tasks, } \\
\text { activities and parameters. }\end{array}$ \\
\hline & \multirow{7}{*}{$\begin{array}{l}\text { Use of } \\
\text { Alternative } \\
\text { Methodologi } \\
\text { es }\end{array}$} & \multicolumn{2}{|c|}{$\begin{array}{l}\text { Some researchers [33-38] had used alternative methodologies and statistical techniques in the project management area. The investigations } \\
\text { had used approach-avoidance theory, Fuzzy logic, NPV etc. for project management. }\end{array}$} \\
\hline 33. & & $\begin{array}{l}\text { The paper described the use of approach-avoidance theory to } \\
\text { develop integrated process model for managing escalation and } \\
\text { de-escalation process in IT projects. Authors had used a } \\
\text { process model to identify conditions, critical incidents, } \\
\text { sequence of actions, and consequences over the life cycle of } \\
\text { the project. The study had been done at various levels of } \\
\text { project, organisation and environments to get an insight into } \\
\text { the approach-avoidance decision of escalation or de-escalation } \\
\text { and the stakeholders' response to the same. }\end{array}$ & $\begin{array}{l}\text { The study suggested that approach avoidance theory may be useful in } \\
\text { some cases, depending upon the critical path activities, incidents and when } \\
\text { to escalate or de-escalate the decisions/ situations to the stakeholders. } \\
\text { Various actions can be categorised into critical to low priority. This would } \\
\text { give a view to the project managers for escalation or de-escalation of the } \\
\text { decisions to the stakeholders. }\end{array}$ \\
\hline 34. & & $\begin{array}{l}\text { This research proposed a conceptual model to represent the } \\
\text { actual project performance. Author had done the feasibility } \\
\text { study by way of questionnaire and interview data. Paper } \\
\text { highlights the management skills and factors required for } \\
\text { managing the project performance and difficulties. }\end{array}$ & $\begin{array}{c}\text { The factors of technical knowledge, estimating skills, critical path } \\
\text { methods, and management skills are required in both the technical as well } \\
\text { as management areas of cost, schedule etc. }\end{array}$ \\
\hline 35. & & $\begin{array}{l}\text { This study focused on the use of Fuzzy logic for critical path } \\
\text { analysis and other PM activities. The approach also } \\
\text { determines the significance of activity and path along with } \\
\text { critical path. This is very useful in risk management and the } \\
\text { method is able to manage the uncertainties. }\end{array}$ & $\begin{array}{l}\text { The study suggested that the fuzzy logic would be quite useful in } \\
\text { determining the activity, its significance along the critical path, and } \\
\text { managing the risk more efficiently. The project manager would have better } \\
\text { view of the critical path and risks and the actions they need to take for } \\
\text { managing the projects efficiently. }\end{array}$ \\
\hline 36. & & $\begin{array}{l}\text { This research paper described that the project success and } \\
\text { performance would be measured in terms of output benefits } \\
\text { realised. Authors explained a technique to establish a cause } \\
\text { and effect relation between output utilisation and target } \\
\text { outcomes. }\end{array}$ & $\begin{array}{l}\text { Paper presented a concept of managing project scope through utilisation } \\
\text { map of the outputs. } \\
\text { The fishbone or cause and effect diagrams, decision tree analysis are } \\
\text { effective tools for mapping \& managing the projects effectively. }\end{array}$ \\
\hline 37. & & $\begin{array}{l}\text { This study discussed the utilisation of Net Present Value } \\
\text { (NPV) as a tool to better project management. Author } \\
\text { highlighted the fact for successful monitoring and controlling } \\
\text { of the project, NPV should be used. This can be the most } \\
\text { important tool for finding the suitable solution. }\end{array}$ & $\begin{array}{l}\text { The author demonstrated that NPV could be one of the most efficient tools } \\
\text { for decision analysis and resolution for successful monitoring and control } \\
\text { of the project. NPV can provide better budget control and managing the } \\
\text { cost and in the process managing the schedule and scope efficiently. }\end{array}$ \\
\hline \multirow[t]{2}{*}{38.} & & $\begin{array}{l}\text { This study described the relationship of project management } \\
\text { with other allied disciplines of in the field of management. } \\
\text { The research is based on the study of } 18 \text { top management and } \\
\text { business journals, publications and then divides them into } 8 \\
\text { categories. The categories are (1) Strategy/Portfolio } \\
\text { Management; (2) Operations Research/Decision Sciences; (3) } \\
\text { Organizational Behaviour/ Human Resources Management; } \\
\text { (4) Information Technology/Information Systems; (5) } \\
\text { Technology Applications/Innovation; (6) Performance } \\
\text { Management/Earned Value Management; (7) Engineering and } \\
\text { Construction; and (8) Quality Management/Six Sigma. }\end{array}$ & $\begin{array}{l}\text { The study suggested that close relationship among various categories and } \\
\text { disciplines. It requires good coordination among various processes and } \\
\text { disciplines for successful completion of projects. } \\
\text { PMs have to use somewhat different skills, techniques, tools to execute, } \\
\text { monitor and control different category of projects. Therefore for web } \\
\text { projects management technique is different form COTS projects, which is } \\
\text { different from infrastructure projects and so on. }\end{array}$ \\
\hline & \multirow{3}{*}{$\begin{array}{l}\text { Effects of } \\
\text { Leadership } \\
\text { and } \\
\text { Management } \\
\text { Qualities of } \\
\text { Project } \\
\text { manager }\end{array}$} & \multicolumn{2}{|c|}{$\begin{array}{l}\text { Effects of leadership and management qualities of project manager along with communication channels for managing projects had been } \\
\text { explored by some researchers [39-42]. The importance of IQ, EQ, and MQ had also been studied. Teaching of proper project management } \\
\text { tools and software is also stressed. }\end{array}$} \\
\hline 39. & & $\begin{array}{l}\text { This research study discussed the impact of personality and } \\
\text { behaviour of project manager on the project types and the } \\
\text { success of the projects. A questionnaire was developed to } \\
\text { evaluate the relationship of project manager's behaviour and } \\
\text { personality with project type and success rate. The four types } \\
\text { of projects considered were Urgent, Complex, Novel, and } \\
\text { Normal and they are judged with three constraints cost, time } \\
\text { and quality of projects. }\end{array}$ & $\begin{array}{l}\text { The study showed that managers with team leading and management skills } \\
\text { and who had better communication skills were more successful than } \\
\text { others. These managers were found to be building an environment of trust } \\
\text { and loyalty with good understanding of human needs. } \\
\text { The motivational techniques are different for different level of people in } \\
\text { the organisation and project managers must be able to address these issues } \\
\text { and the strategy would have to change appropriately for different } \\
\text { complexity of the projects. }\end{array}$ \\
\hline 40. & & $\begin{array}{l}\text { This research paper discussed various issues related to IT } \\
\text { projects such as uncertain, unique, fast changing, short term, } \\
\text { etc. The study emphasised that the project manager play a key } \\
\text { role in successful delivery and implementation of IT projects. }\end{array}$ & $\begin{array}{l}\text { Project managers must explore various communication channels with all } \\
\text { stakeholders so that they can get and circulate proper support and } \\
\text { information from all sides. } \\
\text { This would ensure building long term relations and synergy with clients, } \\
\text { project teams and various stakeholders. }\end{array}$ \\
\hline
\end{tabular}




\begin{tabular}{|c|c|c|c|}
\hline 41. & & $\begin{array}{l}\text { This paper studied the effects of leadership quality on the } \\
\text { success of different type of projects. Authors studied the } \\
\text { impacts of IQ, EQ, and MQ of project manager/ leader on the } \\
\text { success of the projects with different level of complexities. } \\
\text { Study used factor analysis and moderated hierarchical } \\
\text { regression analysis to analyse various responses and data } \\
\text { gathered. } \\
\text { Authors also did variance and non-parametric tests to see the } \\
\text { means and medians of EQ, IQ, MQ, complexity of faith, fact, } \\
\text { and interaction. }\end{array}$ & $\begin{array}{l}\text { Analysis showed that there is a relation between EQ, MQ and project } \\
\text { success but are moderated differently by the complexity of the projects. } \\
\text { EQ and Project success relationship is moderated by the complexity of } \\
\text { faith, whereas MQ and project success relation is moderated by both } \\
\text { complexity fact and faith. } \\
\text { Project success is directly affected by the interaction and its complexity. }\end{array}$ \\
\hline 42. & & $\begin{array}{l}\text { This research paper discussed the issues of teaching project } \\
\text { management as part of system analysis. Most of the training/ } \\
\text { teaching programmes just put emphasis only on drawing } \\
\text { Gantt chart or PERT chart for planning without using proper } \\
\text { PM tools and skills. Therefore, the project plan could not give } \\
\text { a full picture of the project and issues. } \\
\end{array}$ & $\begin{array}{l}\text { Authors suggest that proper tools, skills and techniques must be given to } \\
\text { the aspirants along with proper assignments and tasks. } \\
\text { PMs should use good project and/or portfolio management software for } \\
\text { completing the assignments and tasks. }\end{array}$ \\
\hline & \multirow{12}{*}{$\begin{array}{l}\text { Project } \\
\text { Management } \\
\text { in Global } \\
\text { Distributed } \\
\text { Environment }\end{array}$} & \multicolumn{2}{|c|}{$\begin{array}{l}\text { Managing projects in global distributed has its own challenges [43-66]. Researchers had explored use of different methodologies, techniques, } \\
\text { tools for managing distributed projects from standard processes to incentive based approaches. }\end{array}$} \\
\hline 43. & & $\begin{array}{l}\text { With the exponential growth of communication technologies } \\
\text { and information systems, the globalisation of the commercial } \\
\text { world has also increased significantly. }\end{array}$ & $\begin{array}{l}\text { This research paper highlighted that in order to increase efficiency, } \\
\text { productivity, quality and cost effectiveness, organisations are going for } \\
\text { outsourcing and distributing their wok globally. }\end{array}$ \\
\hline 44. & & $\begin{array}{l}\text { This research study described the importance of software } \\
\text { requirement specification (SRS) document to the success of } \\
\text { global software projects. The authors discussed various } \\
\text { difficulties in creating a standard SRS as companies have their } \\
\text { own methods of creating such documents. }\end{array}$ & $\begin{array}{l}\text { The authors studied how Capgemini overcame the issue of creating } \\
\text { standard SRS by using specification patterns so as to create synergy among } \\
\text { the global teams. }\end{array}$ \\
\hline 45. & & $\begin{array}{l}\text { The significance of knowledge sharing among global teams } \\
\text { and stakeholders and how it can be addressed by mature } \\
\text { processes and tools is highlighted in this study. There will be } \\
\text { lesser readjustment required if the processes, methods and } \\
\text { tools are used enterprise wide. }\end{array}$ & $\begin{array}{l}\text { The authors proposed that enterprise wide software should be used for } \\
\text { project assurance, quality and knowledge sharing. } \\
\text { The software would help provide timely information, data and visibility for } \\
\text { the preventive and corrective actions to be taken for better execution of the } \\
\text { project. }\end{array}$ \\
\hline 46. & & $\begin{array}{l}\text { This study described the team structure for successful } \\
\text { completion of offshore projects. The authors studied two types } \\
\text { of structures for offshore teams and highlighted the problems } \\
\text { faced by managers for changing the team structure and } \\
\text { organisation model. }\end{array}$ & $\begin{array}{l}\text { The paper proposed that changes have to be done to the existing structure } \\
\text { for successful global operations. The team structures for managing } \\
\text { offshore teams for various phases of the project and the reporting structure } \\
\text { has to be managed keeping tin to account various time zone issues, cultural } \\
\text { issues and skills availability. }\end{array}$ \\
\hline 47. & & $\begin{array}{l}\text { A framework for managing risks in global software projects is } \\
\text { proposed in this research paper. The integrated framework had } \\
\text { been created for distributed projects based on various } \\
\text { parameters and requirements of global environment. }\end{array}$ & $\begin{array}{c}\text { The framework proposed the use of various communication channels, } \\
\text { different set of development environment for different needs/ requirements } \\
\text { of the stakeholders and projects. The flow chart could also help to provide } \\
\text { better information across the organisation. }\end{array}$ \\
\hline 48. & & $\begin{array}{l}\text { This research studied the impact of communication media like } \\
\text { email, messaging, phone etc. on the conflict resolution in } \\
\text { global teams. The authors tried to evaluate which could be the } \\
\text { best sequence or combination of media tools for } \\
\text { communication for resolving the conflicts. }\end{array}$ & $\begin{array}{l}\text { The study showed how the cross cultural issues, different communication } \\
\text { channels, time zone management had to be taken into account for } \\
\text { managing global teams/ people effectively. } \\
\text { The process for conflict management has to be robust and transparent so } \\
\text { that the conflicts can be controlled/ resolved in an efficient manner. }\end{array}$ \\
\hline 49. & & $\begin{array}{l}\text { In this study, authors tried to analyse the global development } \\
\text { projects using framework so as to overcome various issues in } \\
\text { the distributed projects. The authors tried to study the } \\
\text { processes used by various organisations to manage the } \\
\text { distributed projects efficiently and effectively, and maximise } \\
\text { the benefits of onshore-offshore delivery. }\end{array}$ & $\begin{array}{l}\text { The paper showed different models and frameworks used by global } \\
\text { organisations to manage the distributed projects successfully. Various } \\
\text { activities can be distributed offshore/ near-shore or onshore and also the } \\
\text { life cycle divided among them for maximising the benefits. }\end{array}$ \\
\hline 50. & & $\begin{array}{l}\text { This research studied different communicating media and its } \\
\text { application the global agile software development projects. }\end{array}$ & $\begin{array}{l}\text { The authors found that instant messaging is a good substitute tool for face } \\
\text { to face communication and email is good tool for wider and enterprise } \\
\text { wide information sharing. }\end{array}$ \\
\hline 51. & & $\begin{array}{l}\text { This research paper proposed predicting the outcome of global } \\
\text { software development projects with the application of } \\
\text { analytical modelling. The analytical models are parameterised } \\
\text { to accommodate the single-site or multi-sites, team sizes, } \\
\text { skills levels, expertise, availability, and support level etc. }\end{array}$ & $\begin{array}{l}\text { The paper suggested various types of models for distributing various } \\
\text { phases/ stages between offshore and onshore sites. }\end{array}$ \\
\hline 52. & & $\begin{array}{l}\text { This research study described the processes for managing a } \\
\text { multi-site software development project is complex and } \\
\text { requires a very good collaboration among teams. }\end{array}$ & $\begin{array}{l}\text { The study suggested management of multi-site projects can be improved } \\
\text { using networked virtual environment which allows for better } \\
\text { communication, familiarity, sharing, mentoring, faith and faster resolution } \\
\text { of conflicts. }\end{array}$ \\
\hline 53. & & $\begin{array}{l}\text { This research studied the growth of teams in distributed } \\
\text { software development projects. The authors had tried to study } \\
\text { the growth of teams in terms of expertise, communication } \\
\text { skills, economic impact and working conditions. }\end{array}$ & $\begin{array}{l}\text { The study described the communication channels, skills and the impact of } \\
\text { virtual communication techniques for successful management of teams and } \\
\text { projects in global environment. }\end{array}$ \\
\hline
\end{tabular}




\begin{tabular}{|c|c|c|}
\hline & & $\begin{array}{l}\text { The better the economic and working condition, the better would be the } \\
\text { team morale and more successful project management. }\end{array}$ \\
\hline 54. & $\begin{array}{l}\text { This research paper explained that the "Distributed Work" is } \\
\text { basically a number of different work provisions. Since the } \\
\text { teams are distributed globally, and are separated by time } \\
\text { zones, the managers have to rely heavily on the availability } \\
\text { and efficiency of communications tools and information } \\
\text { systems. }\end{array}$ & $\begin{array}{l}\text { The research highlighted the importance of communication tools and } \\
\text { information systems for successful management of global teams and } \\
\text { projects. }\end{array}$ \\
\hline 55. & $\begin{array}{l}\text { Use of incentive based theories to the distributed work } \\
\text { environments is described in this research paper. The paper } \\
\text { endeavours to address two subjects; firstly, to understand the } \\
\text { effect of incentives on the worker's choice for using } \\
\text { distributed work environment, and secondly the collaboration } \\
\text { of multiple incentives or disincentives across organisation, } \\
\text { groups or individuals. This paper also looks into motives as to } \\
\text { why people always prefer to take up distributed work } \\
\text { environment. The theory of incentive is applied to two } \\
\text { organisations to understand the behaviour and pattern. }\end{array}$ & $\begin{array}{l}\text { The research suggested that people prefer distributed work environment } \\
\text { because of flexibility, incentives, and availability. The disincentives are } \\
\text { managing different time zones and culture. }\end{array}$ \\
\hline 56. & $\begin{array}{l}\text { This research paper studied as why organisations choose for } \\
\text { distributed work environment. The research was conducted to } \\
\text { understand the use of distributed work environments in terms } \\
\text { of costs, efficiency and productivity, motivation of } \\
\text { employees, and impact on the group's outputs. }\end{array}$ & $\begin{array}{l}\text { The research suggested that the use of distributed work environments is to } \\
\text { mainly reduce the costs, improve efficiency and productivity, motivate } \\
\text { employees, and impacting the group outputs positively. }\end{array}$ \\
\hline $\begin{array}{l}57- \\
60\end{array}$ & $\begin{array}{l}\text { Even though there is clear impact on the employees for the } \\
\text { work-life balance, more flexibility but there are conflicting } \\
\text { observations made which are owing to more distractions at } \\
\text { home which results in increased stress. }\end{array}$ & $\begin{array}{l}\text { These papers showed that remote working, home working or flexible } \\
\text { working is able to provide better work life balance but at the same time } \\
\text { needs more planning as it could also lead to more distractions at home and } \\
\text { less work. The employees have to manage themselves more efficiently to } \\
\text { be more productive. Organisations provide hot-desk facilities to save on } \\
\text { cost of space and also improve its travel carbon footprint. }\end{array}$ \\
\hline 61. & $\begin{array}{l}\text { This research paper defined knowledge intensive firms as } \\
\text { those that "offer to the market the use of fairly sophisticated } \\
\text { knowledge or knowledge-based products". Knowledge } \\
\text { intensive firms can be divided into professional service, and } \\
\text { research \& development firms such as engineering and law } \\
\text { firms or pharmaceutical companies. Knowledge intensive } \\
\text { firms differ from other types of organisations through the } \\
\text { organisation's massive reliance on the intellectual skills of its } \\
\text { employees to carry out its core functions. }\end{array}$ & $\begin{array}{l}\text { Although many of the problems and barriers to distributed work are not } \\
\text { unique to knowledge intensive firms, the sophisticated nature of the } \\
\text { knowledge these firms typically deal in has the potential to magnify these } \\
\text { problems. } \\
\text { This report focuses on the interaction of individuals and teams within } \\
\text { knowledge intensive firms and the ways that they interact and perform } \\
\text { under distributed work arrangements. }\end{array}$ \\
\hline 62. & $\begin{array}{l}\text { This research defined a virtual team as "groups of people } \\
\text { employed in a shared task while geographically separated and } \\
\text { reliant on electronic forms of communication". }\end{array}$ & $\begin{array}{c}\text { The research paper compared various factors such as telephonic } \\
\text { conferences, video conferences, e-mails, time zones, and for managing } \\
\text { virtual teams. } \\
\text { The virtual communication tools are important and also people should be } \\
\text { sensitive to the cultural communication styles and language used in } \\
\text { communication to overcome misunderstandings and reduce } \\
\text { communication gap. }\end{array}$ \\
\hline 63. & $\begin{array}{l}\text { The paper defines the term remote resourcing as "carrying out } \\
\text { work in an office remote from the point where a project is } \\
\text { principally delivered". The report defines remote resourcing } \\
\text { when virtual communication tools are used and teams are } \\
\text { distributed at one or more sites in different geographical } \\
\text { locations. }\end{array}$ & $\begin{array}{l}\text { These terms essentially describe interactions between people separated by } \\
\text { physical distance who perform most of their work through communication } \\
\text { technology. Within the body of this report the term distributed work is } \\
\text { used to represent this concept. The dynamic changes to the project are } \\
\text { handled more effectively when the team is at one place and long-term } \\
\text { projects can get greater benefits from remote teams or by distributed } \\
\text { working. }\end{array}$ \\
\hline 64. & $\begin{array}{l}\text { The research paper discusses that distributed work covers } \\
\text { many alternative methods of work which include satellite } \\
\text { offices, flexible work arrangements, telecommuting and } \\
\text { global collaborative teams. }\end{array}$ & $\begin{array}{l}\text { The paper describes that distributed work could be defined in many } \\
\text { different ways. The distributed teams could use different ways of working } \\
\text { from flexible home working to offshore, onshore or near-shore } \\
\text { arrangements. The paper highlighted that distributed teams and working } \\
\text { are often used to reduce overall cost and improve services. }\end{array}$ \\
\hline 65. & $\begin{array}{l}\text { This paper describes various issues and problems faced by } \\
\text { distributed work faces which are similar to all the issues and } \\
\text { problems that normal collocated group's face, with the added } \\
\text { complexity of workers being based at locations remote from } \\
\text { each other, be it in the next room or in another country The } \\
\text { inclusion of IT as a required element of many definitions } \\
\text { reflects the importance of ICT as a replacement media to } \\
\text { mimic the communicative and collaborative qualities inherent } \\
\text { in collocated work groups. }\end{array}$ & $\begin{array}{l}\text { This paper highlighted that distributed work faces many more problems in } \\
\text { addition to the normal projects at one site. The projects and teams } \\
\text { distributed in different locations brings in the importance of good } \\
\text { communication media and skills, cross cultural issues and management, } \\
\text { time zone management, and clear understanding of the stakeholders' } \\
\text { expectations. } \\
\text { The project documentation has to be detailed and shared with all teams } \\
\text { highlighting various milestones and deliverables and also giving details of } \\
\text { communication requirements. }\end{array}$ \\
\hline 66. & $\begin{array}{l}\text { This research explained that small and medium enterprises } \\
\text { (SMEs) are also facing huge competition due to globalisation } \\
\text { of economies and easier availability of cheaper and good }\end{array}$ & $\begin{array}{l}\text { This paper highlighted that in order to stay ahead of the competition and } \\
\text { technology SMEs should focus on to e-collaborations through project } \\
\text { management approach. This will ensure them structured processes, better }\end{array}$ \\
\hline
\end{tabular}




\begin{tabular}{|c|c|c|c|}
\hline & & quality products, services across the world. & $\begin{array}{l}\text { visibility for managing the full life cycle of the project and giving them } \\
\text { better monitoring and control of project execution. }\end{array}$ \\
\hline & & \multicolumn{2}{|c|}{$\begin{array}{l}\text { Various maturity models have been developed in the area of project management [67-76]. Maturity models help in assessing the capability } \\
\text { and maturity of various processes, tools, techniques and management methodologies in an organisation. }\end{array}$} \\
\hline 67. & & $\begin{array}{l}\text { This research studied the maturity levels of project } \\
\text { management in different industries. They surveyed } 126 \\
\text { organisations based on } 42 \text { components of maturity. } \\
\text { The investigation also studied various industries and formed it } \\
\text { into four groups i.e. professional, scientific, technical services; } \\
\text { information; financial and insurance; and manufacturing. }\end{array}$ & $\begin{array}{l}\text { The research found that maturity level is } 2 \text { out of } 5 \text { w.r.t. } 36 \text { components } \\
\text { out of } 42 \text { analysed. } \\
\text { The results showed that the maturity level of the four groups i.e. } \\
\text { professional, scientific, technical services; information; financial and } \\
\text { insurance; and manufacturing are similar across industries barring a few } \\
\text { exceptions. }\end{array}$ \\
\hline 68. & & $\begin{array}{l}\text { The use of maturity models in improving project management } \\
\text { practice is discussed in this research paper. The paper } \\
\text { analyses the current maturity models for project management. }\end{array}$ & $\begin{array}{l}\text { The analysis showed that the maturity models are mostly used reactively } \\
\text { rather than proactively. The study also emphasised the fact that more } \\
\text { empirical evidence and research is required to establish relationship of } \\
\text { project performance with project management maturity models. } \\
\text { The organisations that are using maturity models like CMMI are found to } \\
\text { be in greater control of the projects since there processes are mature, well } \\
\text { documented and provide good planning. }\end{array}$ \\
\hline 69. & & $\begin{array}{l}\text { This research paper presented a Project Management Process } \\
\text { Maturity (PM) model to evaluate and compare project } \\
\text { management levels of organisations. }\end{array}$ & $\begin{array}{l}\mathrm{PM}^{2} \text { model provides a well-structured model for evaluating project } \\
\text { management maturity level of organisations. The model takes into account } \\
\text { PM processes, factors and characteristics and shows the organisation's } \\
\text { progress from functional to project driven organisation. } \\
\text { The model helps organisations to enhance their project management } \\
\text { approaches, create better documentation and plans. }\end{array}$ \\
\hline 70. & $\begin{array}{l}\text { Project } \\
\text { Management } \\
\text { Maturity } \\
\text { Models }\end{array}$ & $\begin{array}{l}\text { This research paper proposed a maturity model which has thee } \\
\text { maturity levels with continuous improvement group of Key } \\
\text { Process Areas (KPAs). The paper has taken ISO 9001:2000 as } \\
\text { base for quality management. Each KPA is mapped onto plan- } \\
\text { do-check-act (PDCA) cycle. Conical structure is developed } \\
\text { for displaying the gradual development of KPAs in a better } \\
\text { manner. KPAs are developed till they attain a dependable } \\
\text { maturity level for project management. These KPAs may have } \\
\text { to be improved continuously in order to respond to the } \\
\text { changes. }\end{array}$ & $\begin{array}{l}\text { By defining KPAs and then improving those continuously using PDCA } \\
\text { cycle would enable the organisations to manage the projects more } \\
\text { effectively and efficiently. By clear mapping of the KPAs to PDCA cycle, } \\
\text { organisation would be able to improve the management and delivery of } \\
\text { projects continuously. Thus organisations can work to optimise the } \\
\text { processes for effective and efficient delivery of the projects. }\end{array}$ \\
\hline 72. & & $\begin{array}{l}\text { PMI, USA provided a very useful maturity model for } \\
\text { organisations OPM3 to reflect their maturity with the best } \\
\text { practices achieved within the project, portfolio, and } \\
\text { programme domains. }\end{array}$ & $\begin{array}{l}\text { OPM3 tries to link organisational strategy to successful, consistent, and } \\
\text { predictable project completion. OPM3 divides the process improvement } \\
\text { into four sequential stages i.e. Standardise, Measure, Control and } \\
\text { continuously Improve. }\end{array}$ \\
\hline 73. & & $\begin{array}{l}\text { IEEE developed a standard for Software Project Management } \\
\text { Plans (SPMP), IEEE std. 1058-1998. This applies to all types } \\
\text { of software projects and all sizes. }\end{array}$ & $\begin{array}{l}\text { This IEEE standard specifies format and contents of SPMP but does not } \\
\text { specify technique to be used or examples. } \\
\text { This standard provides information and document for managing a software } \\
\text { project } \\
\text { The standard defines the technical and managerial processes necessary to } \\
\text { deliver the project requirements. }\end{array}$ \\
\hline $\begin{array}{l}74- \\
76\end{array}$ & & $\begin{array}{l}\text { Capability Maturity Model Integration (CMMI) provides a } \\
\text { framework for process improvements across the enterprises. } \\
\text { The models have been used in many organisations since } 1995 \\
\text { when the models were first created. }\end{array}$ & $\begin{array}{l}\text { This framework gives applications of principles, practices, and objectives } \\
\text { to achieve enterprise-wide process improvement. } \\
\text { Many organisations have been able to manage budget and times efficiently } \\
\text { with enhanced productivity and quality of projects using CMMI. } \\
\text { Use of CMMI helps organisation to grow from Level1: Initial, Level2: } \\
\text { Managed, Level3: Defined, Level 4: Quantitatively Managed to Level 5: } \\
\text { Optimising. } \\
\text { CMMI provides two representations: continuous and staged. The } \\
\text { continuous representation allows the organisation to focus on the specific } \\
\text { processes that are considered important for the organisation's immediate } \\
\text { business objectives, or those to which the organization assigns a high } \\
\text { degree of risks. } \\
\text { The staged representation provides a standard sequence of improvements, } \\
\text { and gives a basis for comparing the maturity of different projects and } \\
\text { organisations. The staged representation also provides for an easy } \\
\text { migration from the SW-CMM to CMMI }\end{array}$ \\
\hline
\end{tabular}




\section{SUMMARY}

Project management is a very complex field and encompasses technical skills along with man management skills to manage stakeholder expectations. Projects are influenced by both internal and external factors and require various communication channels and techniques to reduce the gap and deliver project effectively and efficiently.

The studies have been conducted to understand the existing standard models [4-8] and adapt them so as to manage projects in a better way. Modifications have been suggested so as to make existing methodologies work in different areas of work. The studied showed that different methodologies could be suitable for different types of projects. It has also been proposed that tailoring of methodologies would be more useful for different scenarios providing efficient and effective project management and control. The studies also showed that large complex system can would be better managed and controlled by dividing the system into smaller modules or phases.

System modelling, dynamic modelling, estimation models and object oriented modelling concepts have been investigated for improving the project management [9-12]. The studies showed that system modelling would be useful to have better communication among different stakeholders by managing various communication means, channels and modes. The studied showed that risks could be forecasted and managed more effectively by the use of dynamic modelling. The studies also showed that object oriented modelling concepts and properties like inheritance, modularity, data-encapsulation, relations could be used to describe the life cycle of the projects and manage it more efficiently. The studies proposed a mathematical model for estimating and forecasting along with the use of iterative development for better monitoring and control of the project.

Software and ICT projects have their own challenges due to rapid technological advances, providing better services, facilities etc. Therefore standard project management methodologies only may not be sufficient for managing project in this area. These methodologies may have to enhance and that's the reason that Agile, JAD, RAD, extreme programming have been developed [13-22]. The studies also showed that project management methodologies/ models should be customised/ tailored for the different projects so as to best fit the scenario and hence avoid unnecessary details and reduce cost and time. The studies also tried to combine different methodologies and framework like RUP, PMBOK, agent framework, metaphors and graphical presentations for creating new frameworks/ models to suit the requirements for managing, controlling, and execution of the project successfully within time and budget. The studies demonstrated that better estimates could be achieved and also stakeholders could manage in a better manner for overall success of the project. The studies also showed that quality control tools/ methodologies like ISO, CMMI would be highly useful in delivering good quality projects.

Stakeholders have different set of obligations, constraints, necessities, and expectations as projects in R\&D organisations are knowledge intensive requiring more sharing of ideas.
These differences have been highlighted in the research papers [23-24]. The studies showed that knowledge sharing areas/ sites for the researchers to share/ propose/ discuss their ideas by using blogs, discussion groups, and chat rooms would be highly useful to enhance creativity and innovations.

Researchers had been able to study various project management methodologies, tools, and techniques etc. empirically and statistically [25-33]. The studies showed that various factors like Management commitment, financial constraints, organisational structure, reward system, education and training of project teams play a crucial role in the successful management of projects. The project managers also tailor their methodology to suit the needs to reduce the cost and time for delivering the projects. The studies also proposed that scope and change management training would be highly useful to project managers for executing, monitoring, and controlling the projects successfully. The studies also showed that in new dynamic environment newer technologies would be more useful than traditional models of development and management of projects. Various techniques like critical path method, PERT, baselining, scope, change, and risk management would be of great help for successful delivery and management of the projects.

They had collected data from various projects to study different areas of project management and analysed it for understanding the effectiveness of various models, techniques or tools. Use of alternative statistical techniques and models such as Fuzzy Logic, NPV, approach-avoidance theory, had been explored in the project management area [33-38]. The studies showed that techniques like NPV, fuzzy logic would be highly useful in estimating and forecasting the project execution with better monitoring and control of the projects. The studies also showed that decision tree analysis, fishbone or cause-effect diagrams could be used effectively to manage quality, risks and deliver successful projects. Project managers need different skills/ tools/ techniques / methodologies to manage various projects efficiently.

Leadership abilities, communication and management abilities along with IQ, EQ, and MQ of the project manager have a huge impact on the projects [39-42]. Teaching of project management is not only about just teaching of GANTT and PERT chart but also must include various software and other tools for successfully managing projects. The studies have shown that project managers should use various communication tools/ methods with different stakeholders. Project managers should have the qualities to be a good team player, manager, having the ability to take decisions with responsibility to deliver successful projects. The studies showed that project manager should be able to manage the expectation of team members, motivating them, understand their training needs and communicate them at different levels so to manage various stakeholders, teams in a better manner and make them more productive.

Distributed environment of projects in the present multinational organisations gives rise to more complexities in all areas of project management [43-66]. Therefore standard project management methodologies have to be enhanced to meet diverse requirements from various stakeholders. The 
studies showed that distributed work environment has its own challenges and advantages. The challenges could be such as managing different time zones, cultural differences, virtual communication environments and costs associated with them, and many more. The advantages could be in terms of providing good quality projects at lower cost. This requires proper documentations, setup the correct expectations, managing various stakeholders and also managing the cross cultural issues effectively and efficiently. The conflict resolution criterion and transparent communication is the key to success in global scenarios and managing successful projects.

Maturity level is able to give the reliability of organisation in a particular area [67-76]. There are a number of maturity and capability levels for project management such as $(\mathrm{PM})^{2}$, OPM3, CMMI, IEEE, etc. against which an organisation can be appraised. The maturity models takes into account PM processes, factors and characteristics and shows the organisation's progress from functional to project driven organisation. The maturity models describe how mature the processes are, the success rate of the organisation in past, and also the probability that it would be able to deliver good quality projects. The organisation could use these models to build robust processes and also optimise them with feedback and changing scenarios and environment.

\section{REFRENCES}

[1] A Guide to the Project Management Body of Knowledge, $5^{\text {th }}$ edition, PMI, USA, 2013

[2] Managing Successful Projects with PRINCE2, OGC, UK, 2009

[3] P3M3-Portfolio, Programme and Project Management Maturity Model, OGC, UK, 2008

[4] Ur Rehman, A., "Software Project Management Methodologies/ Frameworks Dynamics - A Comparative Approach", International Conference on Information and Emerging Technologies, ICIET 2007, Pakistan, 2007, pp 1-5

[5] Schweyer, B., "Formal Specifications For A Project Management Approach", IEEE International Conference on Systems, Man and Cybernetics", Canada, 1995, vol.2, pp 1170-1175

[6] Cederling, U.; Ekinge, R.; Lennartsson, B.; Taxen, L.; Wedlund, T., "A Project Management Model Based On Shared Understanding", Proceedings of the 33rd Annual Hawaii International Conference on System Sciences, Sweden, 2000

[7] Bailetti, A.J.; Callahan, J.R.; DiPietro, P., "A Coordination Structure Approach To The Management Of Projects", IEEE Transactions on Engineering Management, 1994, vol. 41, pp 394-403

[8] Milosevic,D.Z, "Standardizing Unstandardized Project Management", IEEE Technical Applications Conference, Northcon/96, USA, 1996, pp $12-17$

[9] G. Rodrigues, Dr. Alexandre, "Managing and Modelling Project Risk Dynamics A System Dynamics-based Framework", $4^{\text {th }}$ European PMI Conference, London, 2001, pp 1-7

[10] Silva, C. A.; Ferrão, Paulo, "A Systems Modelling Approach to Project Management: The Green Islands Project example", Second International Symposium on Engineering Systems, Massachusetts, 2009, pp 1-12

[11] Lin, Jyhjong; Yeh, Chunshou, "An Object-Oriented Formal Model For Software Project Management", Sixth Asia Pacific Software Engineering Conference, (APSEC '99), 1999, pp 552-559

[12] Ashman, R., "Project Estimation: A Simple Use-Case-Based Model", IT Professional, vol. 6 , Issue: 4, 2000, pp 40-44

[13] Walt Scacchi, "Process Models in Software Engineering", Encyclopaedia of Software Engineering, $2^{\text {nd }}$ Edition, John Wiley and Sons, 2001
[14] Reddy, N.G., "Designing Software Project Management Models Based on Supply Chain Quality Assurance Practices", WRI World Congress on Computer Science and Information Engineering, USA, 2009, pp 659 663

[15] Shlaer, Sally; Grand, Diana; Mellor, Stephen J., "The Project Matrix: A Model for Software Engineering Project Management", $3^{\text {rd }}$ Software Engineering Standards Application Workshop (SESAW III), 1984, USA, pp 1-10

[16] Callegari, D.A.; Bastos, R.M., "Project Management and Software Development Processes: Integrating RUP and PMBOK", International Conference on Systems Engineering and Modeling, ICSEM '07, 2007, Israel, pp 1-8

[17] Hewagamage, Champa; Hewagamage, K. P., "Redesigned Framework and Approach for IT Project Management", International Journal of Software Engineering and Its Applications, vol. 5 No. 3, July, 2011, pp 89-106

[18] Van Wyngaard, C.J.; Pretorius, H.C.; Pretorius, L., "Strategic Management Of The Triple Constraint Trade-Off Dynamics - A Polarity Management Approach", IEEE International Conference on Industrial Engineering and Engineering Management (IEEM), 2011, pp 824 - 828

[19] Sarantis, D.; Askounis, D.; Smithson, S., "Critical appraisal on project management approaches in e-Government", 7th International Conference on ICT and Knowledge Engineering, 2009, pp 44-49

[20] Aguirregoitia, Amaia; Javier Dolado Cosín, José;, Presedo, Concepción, "Software Project Visualization Using Task Oriented Metaphors", Journal of Software Engineering \& Applications, vol 3, 2010, pp 10151026

[21] C Nienaber, Rita; Barnard, Andries, "A Generic Agent Framework to Support the Various Software Project Management Processes", Interdisciplinary Journal of Information, Knowledge, and Management, vol. 2, 2007, pp 149-162

[22] Xu, Shuobo; Xu, Dishi, "Project Management Methodologies: Are They Sufficient To Develop Quality Software" $2^{\text {nd }}$ IEEE International Conference on Emergency Management and Management Sciences (ICEMMS), China, 2011, pp 175-178

[23] Gilbert, M.G., "A Systems Management Approach To Improving Performance And Reducing Risks In Research Projects And Programs", IEEE Aerospace Conference Proceedings, vol. 7, 2002, pp 3467-3471

[24] Dingyong, Tang; Yizhen, Tao; Long, Jiang; Zheng, Cheng, “Application Research of Knowledge Management in R\&D Enterprise Project Management", International Conference on Information Management, Innovation Management and Industrial Engineering, vol. 4, 2009, pp 447-452

[25] White, Diana; Fortune, Joyce, "Current Practice in Project Management-an Empirical Study", International Journal of Project Management, 2002, pp 1-11

[26] Chen, L.Y.; Cian Hui Kao, "The Effects Of Strategic Implementation Of Project Management And Performance", $2^{\text {nd }}$ IEEE International Conference on Information Management and Engineering (ICIME), 2010, China, pp 194-198

[27] Dekkers, C.; Forselius, P., "Increase ICT Project Success with Concrete Scope Management", $33^{\text {rd }}$ EUROMICRO Conference on Software Engineering and Advanced Applications, Germany, 2007, pp 385-392

[28] Berander, P.; Wohlin, C., "Identification of Key Factors in Software Process Management - A Case Study", International Symposium on Empirical Software Engineering, Italy, 2003, pp 316-325

[29] Othman, Marini; Mohd Zain, Abdullah; Razak Hamdan, Abdul, “A Review On Project Management And Issues Surrounding Dynamic Development Environment Of ICT Project: Formation Of Research Area", International Journal of Digital Content Technology and its Applications, vol. 4, no. 1, 2010, pp 96-105

[30] Attarzadeh, Iman, "Modern Project Management: Essential Skills and Techniques", Communications of the IBIMA, vol. 2, 2008, pp 1-9

[31] Jugdev, K.; Mathur, G.; Fung, Tak; " "Project Management Assets And Project Management Performance: Preliminary Findings", Technology Management in the Energy Smart World (PICMET), USA, 2011, pp 1-7

[32] Ghasemabadi, M.A.; Shamsabadi, P.D., "Application Of Five Processes Of Project Management Based On PMBOK-2008 Standard To Run EPM-2010 Project Management System: A Case Study Of Arya Hamrah 
Samaneh Co.", $2^{\text {nd }}$ IEEE International Conference on Emergency Management and Management Sciences (ICEMMS), 2011, China, pp 792-795

[33] Pan, G.; Pan, S.L.; Newman, M., "Managing Information Technology Project Escalation and De-Escalation: An Approach-Avoidance Perspective", IEEE Transactions on Engineering Management, vol. 56, Issue: 1, 2009 , pp 76-94

[34] Deutsch, M.S., "An Exploratory Analysis Relating The Software Project Management Process To Project Success", IEEE Transactions on Engineering Management, vol. 38 , Issue: 4, pp 365-375

[35] Feng, Li; Junyin, Wei, "A Fuzzy Approach for the Project Management", International Conference on Wireless Communications, Networking and Mobile Computing, WiCom-2007, China, 2007, pp 5180-5183

[36] Zwikael, O.; Smyrk, J., "An Engineering Approach For Project Scoping", IEEE $18^{\text {th }}$ International Conference on Industrial Engineering and Engineering Management (IE\&EM), 2011, China, pp 2135-2137

[37] Wetekamp, W., "Net Present Value (NPV) As A Tool Supporting Effective Project Management", IEEE $6^{\text {th }}$ International Conference on Intelligent Data Acquisition and Advanced Computing Systems (IDAACS), Czech Republic, 2011, pp 898-900

[38] Hoon Kwak, Young; T. Anbari, Frank, "Analyzing Project Management Research: Perspectives From Top Management Journals", International Journal of Project Management, 2009, pp 435-446

[39] Hossein Fazel Bakhsheshi, Amir; Rashidi Nejad, Safoora, "Impact of Project Managers' Personalities on Project Success in Four Types of Project", $2^{\text {nd }}$ International Conference on Construction and Project Management, IPEDR-2011, Singapore, vol.15, 2011, pp 181-186

[40] Liu, Shuangqin; Liu, Cheng, "Management Innovation of IT Project Managers", International Conference on Information Management, Innovation Management and Industrial Engineering (ICIII), China, 2010, vol. 3, pp 62-65

[41] Muller, R.; Geraldi, J.; Turner, J.R., "Relationships Between Leadership and Success in Different Types of Project Complexities", IEEE Transactions on Engineering Management, vol. 59 Issue:1, 2012, pp 77 $-90$

[42] Tatnall, A.; Shackleton, P, "IT Project Management: Developing OnGoing Skills In The Management Of Software Development Projects", International Conference on Software Engineering: Education and Practice(SE:EP'96), USA, 1996, pp 400-405

[43] Armstrong, D.; Cole, P., "Managing Distances And Differences In Geographically Distributed Work Groups" in P. Hinds \& S. Kiesler (ed.) Distributed work, MIT Press, 2002, pp. 167-186

[44] Salger, F.; Englert, J.; Engels, G., "Towards Specification Patterns for Global Software Development Projects - Experiences from the Industry", $7^{\text {th }}$ International Conference on the Quality of Information and Communications Technology (QUATIC), Portugal, 2010 , pp 73-78

[45] Salger, F.; Sauer, S.; Engels, G.; Baumann, A., "Knowledge Transfer in Global Software Development - Leveraging Ontologies, Tools and Assessments", $5^{\text {th }}$ IEEE International Conference Global Software Engineering (ICGSE), USA, 2010, pp 336-341

[46] Narayanan, Sidharth; Mazumder, Sumonta; R., Raju, "Success of Offshore Relationships: Engineering Team Structures", International Conference on Global Software Engineering, ICGSE'06, USA, 2006, pp 73- 82

[47] Persson, J.S.; Mathiassen, L.; Boeg, J.; Madsen, T.S.; Steinson, F., "Managing Risks in Distributed Software Projects: An Integrative Framework", IEEE Transactions on Engineering Management, vol. 56, Issue: 3, 2009 ,pp 508-532

[48] Khan, H.H.; Malik, N.; Usman, M.; Ikram, N., "Impact Of Changing Communication Media On Conflict Resolution In Distributed Software Development Projects", $5^{\text {th }}$ Malaysian Conference in Software Engineering (MySEC), Malaysia, 2011, pp 189-194

[49] Lane, M.T.; Agerfalk, P.J., "Experiences in Global Software Development - A Framework-Based Analysis of Distributed Product Development Projects", $4^{\text {th }}$ IEEE International Conference on Global Software Engineering, ICGSE, Ireland, 2009, pp $244-248$

[50] Niinimaki, T., "Face-to-Face, Email and Instant Messaging in Distributed Agile Software Development Project", $6^{\text {th }}$ IEEE International
Conference on Global Software Engineering Workshop (ICGSEW), Finland, 2011, pp 78 - 84

[51] Czekster, R.M.; Fernandes, P.; Sales, A.; Webber, T., "Analytical Modeling of Software Development Teams in Globally Distributed Projects", 5 $5^{\text {th }}$ IEEE International Conference on Global Software Engineering (ICGSE), Ireland, 2010, pp 287-296

[52] Bartholomew, R., "Globally Distributed Software Development Using An Immersive Virtual Environment", IEEE International Conference on Electro/Information Technology, EIT, USA, 2008, pp 355-360

[53] Hashmi, J.; Ehsan, N.; Mirza, E.; Ishaque, A.; Akhtar, A., "Comparative Analysis Of Teams' Growth In Offshore And Onshore Software Development Projects", IEEE International Conference on Management of Innovation and Technology (ICMIT), Singapore, 2010, pp 1163-1167

[54] Hinds, P.J.; Bailey, D.E., "Out of Sight, Out of Sync: Understanding Conflict in Distributed Teams", Organization Science, 2003, vol. 14 (6), pp 615-632

[55] Swan, Bret; Belanger, France; Beth Watson-Manheim, Mary, "Theoretical Foundations for Distributed Work: Multilevel, Incentive Theories to Address Current Dilemmas", IEEE $37^{\text {th }}$ Hawaii International Conference on System Sciences, Hawaii, vol. 1/04, 2004, pp 1-10.

[56] Bailey, D. E.; Kurland, N. B., "A Review Of Telework Research: Findings, New Directions, And Lessons For The Study Of Modern Work", Journal of Organizational Behavior, vol.23, 2002, pp 383-400

[57] Pinsonneault, A.; Boisvert, M., "The Impacts of Telecommuting on Organizations and Individuals: A Review of the Literature", in "Telecommuting and Virtual Offices: Issues and Opportunities", Johnson, N.J., London: Idea Group Publishing, 2001, pp 163-185

[58] Pearlson, K.E.; Saunders, C.S., "There's No Place Like Home: Managing Telecommuting Paradoxes", Academy of Management Executive, vol. 15, 2001, pp 117-128

[59] Belanger, France; Beth Watson-Manheim, Mary; Jordan, D.H., "Aligning IS Research and Practice: A Research Agenda for Virtual Work," Information Resources Management Journal, vol. 15, 2002, pp. 48-70

[60] Igbaria, M., "The Driving Forces in the Virtual Society," Communications of the ACM, vol. 42, 1999, pp 64-70

[61] Alveson, M, "Knowledge Work and Knowledge-Intensive Firms". Oxford University Press, New York, 2004

[62] Hornett, A., "The Impact of External Factors on Virtual Teams: Comparative Cases", in Pauleen, J. (ed.), "Virtual Teams: Projects, Protocols and Processes", Idea Group Publishing, UK, 2004

[63] Turkington, D., "Remote Resourcing", The Beca Infrastructure Board, Auckland 2004

[64] Bélanger, F.; Collins, R.W., "Distributed Work Arrangements: A Research Framework", The Information Society, vol 14, 1998, pp 137152

[65] Cramton, C.D., "Attribution in Distributed Work Groups", in Hinds, P.J.; Kiesler, S. (ed.) "Distributed Work", MIT Press. London, England, 2002, pp 191-212

[66] Mohammad Jafari, M.; Ahmed, S.; Dawal, S.Z.M.; Zayandehroodi, H., "The Importance Of E-Collaboration In SMES By Project Management Approach A Review", $2^{\text {nd }}$ International Congress on Engineering Education (ICEED), Malaysia, 2010, pp 100-105

[67] Grant, K.P.; Pennypacker, J.S., "Project Management Maturity: An Assessment Of Project Management Capabilities Among And Between Selected Industries", IEEE Transactions on Engineering Management, vol. 53 , 2006, pp 59-68

[68] Brookes, Naomi; Clark , Robin, "Using Maturity Models to Improve Project Management Practice", POMS $20^{\text {th }}$ annual Conference, USA, 2009

[69] Hoon Kwak, Young; Ibbs, C. William , "Project Management Process Maturity (PM) ${ }^{2}$ Model”, Journal of Management In Engineering, 2002, pp 150- 155

[70] Sukhoo, Aneerav; Barnard, Andries; M.Eloff, Mariki; A. Van der Poll, John, "An Evolutionary Software Project Management Maturity Model for Mauritius", Interdisciplinary Journal of Information, Knowledge, and Management, vol. 2, 2007, pp 99-118 
[71] EPA Guidance for Quality Assurance Project Plans for Modelling, Office of Environmental Information, EPA QA/G-5M, USA Environment Protection Agency, 2002

[72] Organisational Project Management Maturity Model (OPM3), $2^{\text {nd }}$ edition, Project Management Institute, USA, 2008

[73] IEEE standard for Software Project Management Plans, IEEE std 10581998, IEEE, USA
[74] CMMI for Development, Version v1.3, Software Engineering Institute Process Management Program, 2010, Carnegie Mellon University, USA, 2010

[75] CMMI for Acquisition v1.3, Software Engineering Institute Process Management Program, 2010, Carnegie Mellon University, USA, 2010

[76] CMMI for Services v1.3, Software Engineering Institute Process Management Program, 2010, Carnegie Mellon University, USA, 2010 